\title{
Sustainable Frameworks of Public-Private-Partnerships in Zimbabwe: A Holistic, Sector-Wide Review
}

\author{
Basera Edson ${ }^{1}$ \& Zhou Gideon ${ }^{2}$ \\ ${ }^{1} \mathrm{Ph} . \mathrm{D}$ Scholar, Specialization in Public Management, University of Zimbabwe, Department of Governance \\ and Public Management, Zimbabwe \\ ${ }^{2}$ Senior Lecturer and Associate Professor: Public Policy and Administration, University of Zimbabwe, \\ Department of Governance and Public Management, Zimbabwe
}

\begin{abstract}
In the wake of increasing calls for open governments amid declining external and domestic financial support, Public-Private Partnerships (PPPS) are emerging as viable models of financing infrastructural development and service delivery across the globe. The main goal of this study is to present a holistic, sector-wide review of the genesis, etymology, forms, impact and constraints in the implementation of PPPS in Zimbabwe. In Zimbabwe, the case of PPPs is particularly imperative in view of the recent change in political leadership. The study answered the questions: What measures are being taken to attract-in PPPs? What are the constraining factors? What should be done to mainstream PPP best practices towards increasing private participation towards investment in Zimbabwe? Through desk-research and key informant interviews, the study found that PPPs assist in: sourcing finance, risk management, improving efficiency through technology, employment creation and reduction due to technology. Among its key recommendations are: the revamping of the legislative framework, harnessing the demographic dividend, roll-out PPPs in-basket training workshops, formulate policy documents on PPPs, incentives for risk, ensure community participation through roping-in the traditional leaders as well as systemizing policy consistency and predictability to build investor confidence as framework for sustainable implementation of PPPs in the new dispensation.
\end{abstract}

Key Words: Sustainable, Public-Private Partnerships, Nascent, Mature Market, New Dispensation.

\section{INTRODUCTION}

Internationally, the concept of public-private partnerships is gaining traction in the language and dictum of Public Policy and Management. Admittedly, PPPs are crucial as cooperation between private and public actors is pivotal in public sector investment decisions. They supplement and complement each other to their mutual advantage. In this context, the private player requires guarantees to face the risks encountered in the time gap between the project planning phase and its actual implementation, whereas the public sector requires capital investment, technology and management expertise. In light of the obtaining overstretched financial and material resources facing governments across the globe, the Bretton Woods Institutions such as the World Bank and International Monetary Fund (IMF) are encouraging economies in transition such as Zimbabwe to embrace private-sector led growth culture to attain vision 2030 with a per capita income of at least US\$ 3,500-00.

This article presents the Literature Survey section which outlines the PPP definitional frameworks, its genesis and etymology as well as its benefits and challenges. This section also presents the global PPP experiences and a review on the Zimbabwe PPPs environment with a view to sniff out deficits and identifies international best practices towards sustainable PPP frameworks to quick-start economic growth.

The paper also highlights the problem definition and methodology section which employed documentary review for secondary data as well as key informant interview as primary data gathering tool to identify PPP challenges, impact of PPPs as well as measures that can be employed towards sustainable PPP frameworks in Zimbabwe. The article also highlights and discusses the primary data findings on the PPP experiences in both the local governance and agricultural sectors in Zimbabwe. In view of the government's pressing needs for engaging private participation to achieve economic growth and development, the paper concludes 
by highlighting the proposed measures to strengthen sustainable PPP frameworks in the sampled agricultural and local government sectors in Zimbabwe, and the Zimbabwe PPP environment in general.

\section{LITERATURE SURVEY}

Literature Review is a critical appraisal of the existing body of collected works with a view to find salient points on a given subject as well as identifying gaps on the subject, and the global best practices that can be replicated to solve the problem under study.

\subsection{Definitions of PPPs}

It is important to note that there is no generalizable definition on Public-Private Partnerships (PPPs). A PPP can be defined as a long-term contract between a government entity and a private player, for the purpose of providing a public asset or service (Sulser 2018). In this case, the private party bears substantial risk and management responsibility and remuneration is linked to performance. From the foregoing definition, it is evident that the private player plays an integral role as it takes responsibility to deliver the design, feasibility, construction, implementation, operations as well as maintenance of the project.

Similarly, the World Bank (2019) defines PPPs as a way of contracting for developing and maintaining infrastructure services using private sector innovation and skills to manage operations that often leverage private finance. On the same note, UNCTAD (2018) defines PPPs as cooperative project between the private and public sectors, on a long-term basis (can range from a few up to 30 or more years), for the provision of a public asset and or public services, sharing of risks, responsibilities and rewards between the project partners.

From the national laws and policy perspective, the Canadian Council for Public-Private Partnerships (not dated, available on: http://www.pppcouncil.ca/web/knowledge-centre/what-are-P3s/definitions-models/., accessed 11/11/2019) defines PPPs as cooperative ventures between the public and private sectors, built on the expertise of each partner that best meets clearly defined public needs through the appropriate allocation of resources, risks and rewards. In the same vein, the European Commission (2003) defines a PPP as an arrangement between two or more parties who have agreed to work cooperatively toward shared and or compatible objectives and in which there is a shared authority and responsibility, joint investment of resources, shared liability or risk-taking, and ideally mutual benefits.

In its further definition of PPPs, the World Bank (2019a) in its on-line article, What PPPs is not: Other types of private involvement, acknowledged that governments enter into a wide range of contracts or arrangements with private companies. In this respect, these contract types share some of the PPP characteristics such as being long-term, output based, or performance related but they are not PPPs as defined above. In this context, the Bank asserts that management contracts do not share the long-term characteristics of PPPs, the significant private capital investment, and the high level of responsibility for long-term performance brought by investment in infrastructure. However, the Bank further argued that management contracts typically include similar performance indicators and requirements to PPPs. In this regard, performance incentives are created primarily through payment and penalties scheme. The World Bank further averred that being performance based, management contracts have a role to play where the private sector is not willing to invest or where government is not willing to make long-term contract.

Elucidating the foregoing argument, Groom et al. (2006, p. 36 - 42 cited in the World Bank 2019a)'s explanatory notes on water regulation, for instance, described how management contracts are used in the water sector. In that vein, operations and management as well as performance based maintenance contract may also fall outside the PPP definitional frameworks to the extent that they are of a short-term duration and lack substantial investment by the private operator in nature.

Both the United Nations Conference on Trade and Development (UNCTAD) (2018) and World Bank (2019a) categorized affermage contracts as falling outside the PPP definitional frameworks. The international development organizations attest that in their nature, a government delegates management of public service to a private company in return for a specified fee. In particular, the World Bank established that in an affermage contract, in the water sector, the remuneration of the operator is a fixed amount per cubic meter of water sold and is subject to adjustment based on inflationary trends. In this respect, both UNCTAD and the World Bank argued that to the extent that affermage contracts have no infrastructure investment by the private operator, they fall outside the purview of PPPs.

Further to the above observations, both UNCTAD (2018) and World Bank (2019b) argue that while financial lease are long-term contracts for providing public assets, these contracts, however, transfer significantly less risk to the private player than PPPs because government maintains a larger portion of risk than it normally would be in a PPP framework. In this regard, therefore, financial lease contracts do not transfer significant responsibility for management and performance to the private party. Resultantly, financial leases do not produce significant improvements in service performance or reach efficiency gains. 
On a similar note, the World Bank (2019b) established that while design-build, or turnkey contracts include similar output based specifications, however, as short-term agreements that do not include maintenance or operation, they do not create the same longterm performance incentives as those of PPPs. Finally, UNCTAD (2018) averred that since in privatizations, the government permanently transfers public assets (and the responsibility to provide a service) to the private sector, the public sector therefore frees itself from any responsibility and ownership and all risks are fully born by the private actor. To the aforesaid extent, privatization is not PPPs.

\subsection{Types of PPP Contracts}

PPPs exist in various forms of contracts depending on the nature of agreement between the government and the private player.

Table 1: Types of PPP contracts and their definitional frameworks

\begin{tabular}{|c|c|}
\hline Contract type & Definition \\
\hline $\begin{array}{l}\text { 1. Design-Build-Finance-Operate-Maintain (DBFOM), Design- } \\
\text { Build-Finance-Operate (DBFO), Design-Construct-Manage- } \\
\text { Finance (DCMF) }\end{array}$ & $\begin{array}{l}\text { These types of contracts are defined by the functions } \\
\text { transferred to the private party. Functions of the private } \\
\text { investor may be as outlined in the wording or contract, } \\
\text { to design, build, construct, finance, operate and or } \\
\text { manage as implied by the titles of the contract types. }\end{array}$ \\
\hline $\begin{array}{l}\text { 2. Build-Operate-Transfer (BOT), Build-Own-Operate-Transfer } \\
\text { (BOOT), Build-Transfer-Operate (BTO), Build-Own-Operate } \\
\text { (BOO) }\end{array}$ & $\begin{array}{l}\text { These contracts are described with regards to the legal } \\
\text { ownership of the project assets. } \\
\text { Under a BOT project, the private company owns the } \\
\text { project assets during the life time of the project, but } \\
\text { transfers them to the public sector at the end of the } \\
\text { contract. BOOT and BOT are used interchangeably. } \\
\text { Unlike BOT and BOOT where ownership is transferred } \\
\text { at the end of the contract, under a BTO contract term the } \\
\text { asset ownership is transferred once the construction is } \\
\text { complete. } \\
\text { BOO contract is similar to BOOT contract but the } \\
\text { private party retains ownership of the asset (the } \\
\text { government only agrees to purchase the services } \\
\text { produced for a specified length of time. The IPPs and } \\
\text { Power Purchase Agreements fall under this category. }\end{array}$ \\
\hline 3. Concession & $\begin{array}{l}\text { A concession gives the private party a long-term right to } \\
\text { use the public assets in question but also assigns the } \\
\text { private party the responsibility for operations and some } \\
\text { investment. } \\
\text { In this category, asset ownership typically remains with } \\
\text { the public sector and the private party obtains most of its } \\
\text { revenues directly from the consumer ("user-pays" PPPs) }\end{array}$ \\
\hline 4. Operations and Maintenance & $\begin{array}{l}\text { Under this category, the private investor is responsible } \\
\text { for operations and management of the PPP. Noteworthy } \\
\text { is that it is considered as a PPP to the extent it is } \\
\text { performance based and long term and involves private } \\
\text { investment }\end{array}$ \\
\hline
\end{tabular}

Source: Compilation based on the World Bank, Chilean Concession law and Delmon (2010: p. 12).

\subsection{Rationale for PPPs}

Globally, governments and international organizations are motivated to employ PPPs for the following reasons:

According to Sulser (2018), first, well-functioning and accessible infrastructure is fundamental to social and economic development as it provides vital life necessities such as clean water, power and cooking gas, among other needs, to citizens and it converts them to their jobs, health care facilities and schools. Noteworthy is that infrastructure supports the physical transportation of goods to markets and the virtual connection of markets to one another to enhance trade.

Second, in spite of the above importance of a superb infrastructure, there is a glaring gap on the scale of the scarcity of basic infrastructure that was historically provided by governments in developing countries. To substantiate the above gap, the World Bank (March 2017 study cited in Sulser 2018) indicates that gaps in the water infrastructural facilities, electricity and adequate ports, airports and road ways impede economic growth in developing countries.

In view of the above infrastructural deficit, Dobbs et al. in the McKinsey seminal 2013 report, Bridging Global Infrastructure Gaps, asserts that US \$3.3 trillion worth of total investment is required to close infrastructure gap across the globe. In developing 
countries, US\$ 1 trillion is spent on infrastructure refurbishment and constructing new ones, 80 percent of which comes from the national fiscus. McKinsey went on to estimate that by 2030, developing countries would need over US\$ 10 trillion dollars or about US\$ 900 billion per year. Notwithstanding the enormous infrastructure investment needed, governments of developing countries inclusive of Zimbabwe have overstretched public financial resources. Thus, private sector investment is regarded as an impeccable engine to support the overstrained budgets of governments to deliver basic services. Against the backdrop of infrastructure backlogs, limited public finances as well as the capacity to address the problem, one viable option to mobilize private sector resources is through adopting PPP frameworks.

The World Bank (2017) noted that when well-designed and implemented in a developed, balanced and predictable regulatory environment, PPPs can usher efficiency and sustainability to water supply, sanitation, energy, transportation, telecommunications, health and education, prison operations, garbage collections, among other essential public services.

Noteworthy is that PPPs are aligned with some of the Sustainable development goals. In this respect, governments and government entities, the G20, the United Nations and many development institutions (DFIs) view PPPs as vehicles for development as they contribute to a number of the United Nations Sustainable Development goals (SDGs) adopted in September 2015, such as water supply and sanitation (SDG 7), education (SDG 4), affordable and clean energy (SDG 7) as well as other traditional infrastructure such as health, roads, rail, airports and ports (SDG 9).

Boudot (2014) argues that PPPs assist government because they compensate for deficiencies in management of services, thereby strengthening government's programming and contracting capacities. Furthermore, PPPs contribute to financial autonomy of local governments and state-owned enterprise (SOEs). PPPs promote sectoral dialogue and private sector involvement. They also foster innovation and technological know-how in the country.

However, Boudot (2014) argues that PPPs can increase budget constraints if they are not managed properly. Boudot further asserts that PPPs require robust legal framework and good governance which seem to be a toll order in developing countries such as Zimbabwe. Usually governments have complex tasks to ensure the balance between protecting consumers and making the project attractive enough for the private sector. Scholars under the principal-agent theory assert that the state as the agent has the responsibility to maximize social returns through meeting SDGs while the private sector as the agent intends to maximize profitability through cutting costs.

\subsection{Global Success Stories on Sustainable PPP frameworks}

This section outlines and discusses the international best practices towards strengthening the sustainability of PPPs as infrastructural development financing models using the cases of India and Ontario in Canada.

\subsubsection{The Case of India}

The Government of India offers enviable performance in the strengthening of PPPs sustainability. For example, it provided incentives to PPP projects to strengthen their sustainability. In this case, with regards to infrastructural projects that are economically justifiable but not commercially viable, the government gives 20 percent of project cost to private investor selected on a competitive bidding basis under the viability gap funding model. In this respect, a set of guidelines have been set to ensure PPP activities are conducted in a more transparent and competitive manner (Yadav and Yadav 2008).

Further to the above best practices, the Yadavs (2008) highlighted that there is a PPP unit located within the Ministry of Finance, which unit plays a coordinating and supervisory role in PPP projects and there is intensive capacity building at both state and central government levels. Further to above, IMF recommended strong and independent regulators to bolster investor interest. In the same vein, regional and international development organizations such as the Asia Development Bank, United Nations Development Program (UNDP), World Bank as well as United States Agency for International Development (USAID) have played critical roles in promoting aggressive PPP policy for India's long-term growth and development. Resultantly, because of embracing public-private partnership best practices in public administration affairs, there was corresponding increase in Gross Domestic Product in India as it rose from 5.5 percent between 1990 and 2000, six point six (6.6) percent between 2000 and 2005 and more than 9 percent afterwards, a trend which made India the economic powerhouse in Asia.

Examples of sustainable PPP projects in India include empowerment of farmers, power sector development, urban rejuvenation, transport systems and world-class infrastructure in the health, education and water sectors (Yadav and Yadav 2008).

\subsubsection{The Case of Ontario in Canada}

According to Himmel and Siemiatycki (2017), the case of Ontario in Canada offers a success case as it embraced competitive bidding in tenders, incentives as well as community engagement in PPP projects selection and appraisal. Ontario government's 
organizational and coordinating role also assisted in strengthening PPP sustainability. According to Raumboutsos and Saussier (2014, Winch 2012 cited in Himmel and Siemiatycki 2017), Ontario embraced innovation through introducing inventive ways of doing things. These inventions include creative ways of meeting the performance specifications at a lower cost, through inter alia, substituting expensive materials, improving energy efficiency or developing inventive construction approaches that reduce the time or lower risk. Usually, innovation culture is made through embracing incentive structures and risk allocations into PPP models.

Examples of successful PPP projects in Canada include the 2013 Waterloo Courthouse cited by the American Institute of Architects (2013) as the best design in the courthouse sector. Similarly, the Union Express PPP project (Air Rail Link Spur) was highly designed by Ontario despite accompanying disturbances such as low ridership which was replaced by reduction in train fares and subsidy. Further, there was pollution produced from diesel run trains.

\subsection{An empirical review of the Zimbabwe PPPs scenario}

Both empirical and documentary reviewed researches carried-out on PPPs in Zimbabwe point to a plethora of factors impeding the smooth implementation of PPPs. Massimo (2014) highlighted political and economic uncertainty, waning market confidence with regard to policy implementation and an absence of a sound legal framework to guide implementation of PPPs, as impediments. In the same vein, Zhoushe and Zhou (2015) together with Zinyama and Nhema (2015) found that there are major gaps in legislation, unavailability of specialized PPP units, unsupportive investment policy frameworks as well as high levels of investment risk. In addition to the above, there is lack of financial resources, currency risks, and lack of PPPs expertise, gaps which constrain the smooth implementation of PPPs.

Through a documentary review, Zinyama and Nhema (2015) tracked the PPP milestones in Zimbabwe. The first milestone is the 2004 PPPs in Zimbabwe Policy Guidelines. The guidelines tried to provide parameters for legal and regulatory frameworks with a view to protect investors and consumers. The Zimbabwe National Chamber of Commerce (ZNCC) (2009 study cited in Zinyama and Nhema 2015) stated that there were three successful projects such as the Beitbridge Bulawayo Railway (BBR), New Limpopo Bridge (NLB) and the Newlands Bypass (NBP). In their study, Zinyama and Nhema (2015) established that NLB was completed in 2007 on a Build Transfer (BT) basis as the constructor handed over the project to government upon completion. In the same respect, NLB involved the financing and building of a toll bridge over Limpopo River. The private player was awarded a tender in 1993 by the Zimbabwe and South African governments under a BOT basis. In 2015, the NLB private limited, a private limited company was still operating the bridge and has managed to computerize its systems to ease procedures for crossing the border and aid the promotion of trade and development.

Zinyama and Nhema (2015) further highlighted that the BBR is a project that was implemented in Zimbabwe on a BOT basis by Beitbridge Bulawayo Railway (Pvt) 1td, a subsidiary of NLPI ltd of South Africa, a company which was established to implement the project. The motive behind BBR construction was to facilitate the smooth transportation of fuel into Southern part of Zimbabwe from South Africa.

In addition to the above cases, Nkomo and Nhema (2015) cited the Plumtree - Mutare Highway which was awarded to South African Group Five for resurfacing and maintenance. Bhoroma (2018) highlighted that the above $820 \mathrm{~km}$ rehabilitation was completed a year ahead of schedule. Despite the above success case, there are still road networks that demand attention such as the Beibridge-Harare-Chirundu highway and the dualization of the Harare-Bulawayo road (Ibid). In this respect, Bhoroma further cited the US\$600 million Chisumbanje Ethanol Plant Project by Green Fuel and the Agricultural and Rural Development Authority of Zimbabwe (ARDA) as another success story completed ahead of schedule in 2013.

The second milestone in PPPs development was during the Government of National Unity (GNU). In this regard, Zinyama and Nhema (2015) established that the Short-Term Emergency Recovery Programmes (STERPs 1 and II) advocated for the use of PPPs in areas such as air, railway services, power generation, dam construction and national highways. They further averred that between 2009 and 2010, a series of PPP workshops were undertaken focusing on gaps to be closed for the successful implementation of PPPs, being guided by international best practices. One critical recommendation was the need to speed up the policy and institutional frameworks for PPPs to allay fears from private investors. It is worth pertinent to note that at the time of writing this article, to show its deep-commitment with regards to embracing private participation towards efficient public service delivery, the new dispensation has now located the Joint Venture Unit (JVU) as a PPP unit in the Office of President and Cabinet. This new Joint Venture Unit is now housed in the Zimbabwe Investment and Development Agency (ZIDA). Noteworthy is that at the height of the GNU, the Office of the then Deputy Prime Minister, Professor Authur Mutamabara made significant strides in the formulation of PPP policy guidelines. In this vein, critical documents such as the PPPs policy 2010, PPPs Legislative Review for Zimbabwe 2010 and the Institutional Framework: PPPs 2010 were made (Zinyama and Nhema 2015). 
The third PPP milestones in Zimbabwe according to Zinyama and Nhema (2015) is the Zimbabwe Agenda for Sustainable SocioEconomic Transformation (ZIMASSET) blueprint which identified PPPs as financing instruments towards infrastructural development. In the ZIMASSET document, PPPs were to be used in the transport sector, road infrastructure, power sector, education sector, water and sewer reticulation, health sector, dam construction, among others.

Fourth, the new dispensation recognizes that the adoption of PPPs assists in mobilizing private capital to finance key infrastructure projects, at a time when Government has limited resources. The Transitional Stabilization Programme (TSP) as the fourth milestone states that Implementation of projects through PPPs will be broadened in line with Zimbabwe's capacity to manage the PPP process, targeting sectors such as energy, transport, housing and water. In the same vein, the Program reckons that crowding-in private sector funding will entail development of a robust and bankable pipeline of projects ready for the market, requiring investments in project preparatory activities, including feasibility studies, to make evidence-based infrastructure decision-making. For PPPs to be sustainable, Short-term transitional plan maintains that billed amounts are collected, not only for financial stability, but to enhance the creditworthiness of parastatals and local authorities, which in turn enhances their capacity to mobilize funding from the private sector. In this regard, the new dispensation had established a robust institutional framework to quick-start development planning especially in the area of private sector -led infrastructural development.

A holistic, sector-wide review of the Zimbabwe PPPs scenario shows that while there are four phases in the PPP country environments such as 'nascent', 'emerging', 'developed' and 'mature' markets according to the Economic Intelligence Unit (2015), Zimbabwe is under the PPPs emerging/developing phase. In this light, to consolidate the developing stage and graduate into PPPs mature markets, there is need for the government to enhance sustainable PPP frameworks across the economic and social sectors. This article lays a foundation for sustainable PPP frameworks. It is important to note that sustainable partnerships should be able to balance between private returns and public returns in line with Sustainable Development Goals. In this regard, a Sustainable PPPs framework should be able to harness demographic dividends through ensuring the participation of women and youths in infrastructural projects for continuity (Social Sustainability), Economic Sustainability (should at least have fees that will guarantee its sustainability into the future), Environmental Sustainability (ensure that it protects the climate through climate change adaptation and mitigation).

\section{PROBLEM DEFINITION AND METHODOLOGICAL FRAMEWORK}

In the wake of increasing call for governments across the globe to adopt PPP best practices with a view to improve fiscal space, foster innovation and creativity, create employment and improve efficient and effective service delivery, both empirical and documentary researches indicate that in countries such as Zimbabwe, PPPs in various sectors are not sustainable due to various challenges. Against this background, this study used documentary review through the use of desk-top research whereby global experiences on sustainable PPP frameworks, PPP definitional frameworks as well as PPPs Scenario on the Zimbabwean environment were discussed with a view to nudge policymakers towards sustainable PPP frameworks. In addition to the above methods, key informant interview was used targeting key respondents drawn from local governance and agricultural sectors in Zimbabwe. In the agriculture sector, the key respondents comprise agriculture experts drawn from the private players, agricultural and extension service workers at provincial and district levels. In the local governance sector respondents included Chief Executive Officers for local authorities, council finance officers, district and provincial development coordinators drawn from the Ministry of Local Government and Public Works as well as private player partners. The study whose principal aim was to examine the challenges impeding the sustainability of PPPs in both the agricultural and local governance sectors in Zimbabwe, targeted twenty (20) respondents in each of the identified sectors drawn through purposive sampling. The study used a key informant interview guide to answer the following questions. 1. What are the experiences in the sector and why is it important to attract PPPs in this sector? 2. What measures are being taken to attract-in PPPs in this sector? 3. What are the major achievements of PPPs in this sector? 4. What are the major challenges impeding the sustainability of PPPs in this sector? 5. What measures should be implemented to strengthen PPP sustainability in this sector? The study used qualitative approach in analyzing and discussing its findings.

\section{RESULTS AND DISCUSSION}

This section outlines and discusses the PPP experiences in both the agriculture and local governance sectors in Zimbabwe.

\subsection{PPP experiences in the sampled Agricultural sector in Zimbabwe The agricultural sector}

In terms of experiences, twelve (12) out of twenty (20) targeted key informants in the agriculture sector (60 percent response rate) concurred that for the past twenty years there is roller-coaster performance of the agriculture sector in Zimbabwe in terms of productivity. In this respect, climate change is there to stay and it has affected maize production while tobacco production is on an 
upward trend. More so, the agricultural sector has experienced declining infrastructure such as curing barns, irrigation infrastructure, farm bridges, among other examples.

Key informants in the sector highlighted that it is important to attract PPPs to boost agricultural production and productivity. First, respondents highlighted that there is need to unlock potential in the sector and PPPs are viewed as sustainable sources of funding in this regard. Second, PPPs are instrumental in resuscitating infrastructure and upscale Research and Development (R \& D). In this case, $\mathrm{R} \& \mathrm{D}$ is crucial to find techniques to adapt to climate change as it assists in availing varieties that are resistant to climate change. Third, PPPs help to inculcate ownership between government, investors and the people. Fourth, PPPs assist in resuscitating dying parastatals in the agriculture sector. For example, the Agricultural and Rural Development Authority of Zimbabwe (ARDA) was underperforming before rolling-out of PPPs. Fifth, PPPs are playing a crucial role in upgrading the overall agriculture value chain. In this respect, PPPs are at various levels of the agriculture chain such as input production and supply, Research and Development, finance and marketing as well as green agriculture. Sixth, PPPs promote economic development through employment creation as well as increasing export capacity basing on the promotion of import substitution.

\subsubsection{Measures being taken to attract-in PPPs}

Firstly, in 2017 there was government pronouncement on Joint Venture Act and PPPs Act under the ten point plan. The 2017 pronouncement tried to address institutional and legal gaps in the 1990s as PPPs lacked the aforementioned necessary operating frameworks. There is consistency in implementing those legal and institutional frameworks particularly in the President Emmerson Mnangagwa-led new dispensation which was established in November 2017.

Secondly, there is significant drive in parastatals themselves as they are involved in hunting for private players and linking them to farmers. In this regard, ARDA has a graduation programme in which they are merging farmers and investors to create a wide pool of resources such as land, finance and technical expertise. Government is a kind of mediator not a player as it mediates the linkage process. Third, there is massive drive for value addition and beneficiation as it sets the tone for enabling legal and institutional frameworks for value chain. Fourth, there is political will by the government through policy pronouncement such as the 'Zimbabwe is open for business mantra', scrapping of the 49-51 percent equity law in the indigenization and empowerment Act, and the ongoing compensation for the victims of the land reform programme who are the former white commercial farmers under the US\$ 3.5 billion Global Compensation Agreement, among other measures.

\subsubsection{Impact of PPPs in the Sector}

Respondents highlighted the partnership between ARDA and Trek Fuel Giant. In this case, there was huge investment in irrigation infrastructure in Matabeleland North, Matabeleland South as well as Mashonaland West provinces. More than 3000 hactures of land was put under crop-plant utilization in winter and summer targeting maize, wheat, soya beans, small grains and animal husbandry. The partnership has also invested in hi-tech cereal driers to ensure timely harvesting of grain and drying at 12.5 percent moisture content, modern equipment (350 HP Casey tractors which can pull 24 disc harrows each), 12 centre pivots to irrigate more than 520 hactures, grading shades, among other infrastructural developments. According to Scoones (2016), ARDA has a substantial land holding across the country including 21 estates of varying sizes with a total of 98,000 hactures of arable land of which 19,000 hactures is irrigable. In this regard, financing of its operations became increasingly challenging as the government issued bonds via the Agricultural Marketing Authority (AMA), without success.

With regard to production, the ARDA-Trek joint venture is feeding into the strategic grain reserve with 7000 tonnes of wheat and close to 10000 tonnes of maize, soya bean and other crops. In addition, the partnership is creating employment and supply raw materials to the manufacturing industry. It is also involved in certified seed production of maize, soya bean, and small grain as food security follows seed security. However, Scoones (2016) presents mixed reaction on employment as ARDA highlights that more than 200 jobs have been created by the partnership, while arguments attest to the effect that due to technology, 3 sectional managers in the past were reduced to one, 90 permanent workers were reduced to 48 and hundreds of temporary workers who were employed before the partnership to detassle maize for a 7 day contract were reduced to 162.

There is also the ARDA-Delta Schweppes partnership under the Best Fruit Processor, a joint venture to resuscitate a fruit processing plant in Norton, a town which is located 30 kilommetre peg along the Harare to Bulawayo highway, and they are exporting 70 percent of the products to Botswana and other countries in the Southern African Development Community (SADC) region. Products include tomatoes, butter nuts and orange juice.

The ARDA-Delta Synergy has some upstream value chain upgrading implications as it employs bankers for finance and farmers as suppliers. In the downstream, value chain upgrading implications is employment creation and export generation as it feed into retailers, consumers and exporters. To confirm the findings from interviews, Rusare (2016) highlights that it creates direct employment of 100 people, and indirectly, 3000 farmers are assisted for the out-growers programme. In partnership with ARDA, 
the company developed 300 hactures of tomatoes, 200 hactures of oranges and 200 hactures of mangoes at ARDA Sanyati Estate which is located in the Kadoma district in the Matabeleland West Province of Zimbabwe.

\subsubsection{Key factors constraining sustainability of PPPs in the sector}

First, the land tenure system poses a challenge to investors as land belongs to the state and in terms of bankability, it has no value and therefore appropriate finance for agribusiness will not be attracted as there will be no collateral security.

Second, the current inflationary pressures are distorting both input and output prices. There are distorted local market prices and determining of selling price is difficult. Related to the foregoing is the volatile political environment.

Third, there are ease and cost of doing business challenges as loans are currently expensive. For example, the lending rate ceiling in October 2019 was 108 percent per annum although it has reduced to below 40 percent by September 2020.

Fourth, there is intellectual brain drain as many graduates are leaving the country for greener pastures.

\subsection{The local Government Sector}

Fifteen (15) key informants out of a target of 20 informants (75 percent response rate) highlighted that for the past two decades, local authorities in both towns-cities and rural areas have been experiencing challenges in terms of resources and efficient service delivery. For example, in most towns and growth poles there is shortage of water, poor sewer reticulation as well as underutilization of local resources.

In view of the above experiences, respondents highlighted that it is important for local authorities to enter into PPP arrangements to first of all improve efficiency in service delivery. Second, PPPs help in unwinding red tape through cutting bureaucracy and improve decision-making. Third, PPPs provide new technology as the private players will be operating on a higher note as opposed to the conventional model of operations by local authorities. Fourth, these arrangements assist in the transfer of risk as the risk of borrowing will be absorbed by the private sector and the same objective financing infrastructural development will be achieved. Fifth, respondents cited that since the Rural District Development Act and the Town and Urban Councils Act empower councils to undertake commercial activities such as power generation, commercial banks, setting up companies, among other lucrative ventures, PPPs will thus bring innovation and creativity. Six, private players are fully equipped with assets such as experimental rooms, soil sampling, state of the art/modern road equipment and expertise. Seven, specialization by private players in areas such as provision of water, purification, sewage facilities, and housing project development, among others, make partnerships important in service delivery. This is very critical given that private players are registered with International Standard Organization (ISO) certification for quality assurance.

\subsubsection{Measures being taken to attract-in PPPs}

Thus, in order to attract-in PPPs in their affairs, local authorities in Zimbabwe are participating in international trade fairs and agricultural shows. Through channels such as websites, social media platforms - Whatsapp, Instagram, Facebook, among others, both public and private print-electronic media space, local authorities publish newsletters detailing their success stories and investment opportunities on defined intervals. To give impetus to the tone of private participation in local governance affairs, since 2017 there are many sensitization programmes for partnerships. These workshops have been focusing on capacity building for policy-makers such as council chairpersons, mayors and town secretaries with a view to expedite resolutions and decisionmaking in the ease of doing business reforms. In this regard, international development agencies such as the UNDP, ministers, Rural District Council Associations and Government of Zimbabwe are partnering to offer training in PPPs.

\subsubsection{Impact of PPPs in the Sector}

With regards to major achievements of PPPs in local governance affairs, while many local authorities are intending to benefit from PPPs, in some local authorities such as Nkayi, Bubi, Lupane and Umguza, all in Matabeleland North Province, PPPs led to the establishment of clinics, piped water schemes, schools, dip-tanks and livestock breeding given that cattle rearing is the mainstay of the Matabeleland region's local economy, road rehabilitation and construction as well as lucrative joint ventures between council and private players on timber-logging and gold mining. Furthermore, PPP models have assisted in inculcating efficiency and entrepreneurial skills to council employees. In most cases where PPPs have been implemented, it was done with easiness due to expertise.

\subsubsection{Key factors constraining sustainability of PPPs in the sector}

While some PPP projects have succeeded, others are failing to kick-off due to shortage of funds as well as mistrust between the council and private players. An example in this respect is the intended joint venture partnership between Bubi Rural District Council (BRDC) and Highway Petroleum in Matabeleland North. Others include the partnership between BRDC and G5 in gold 
extraction which faced resistance from the community due to limited community engagement. In addition to the above, the Lupane Methane Gas Project, which is an intended partnership between Lupane Rural District Council and Chinese Sunlight Investment Company has been stalled due to Environmental Management Agency (EMA) exorbitant environmental impact assessment fees. In this case, the investor will have to pay EMA debts for the partnership to kick-off.

Interviewees in the local governance sector also cited main challenges impeding the sustainability of PPPs in the sector. As one respondent cited, “...PPPs area is blurred in local authorities". The implication of the tone is that there is lack of definition on PPPs in many forms and shapes. There is no template to define and standardize them. Relatedly, local government in Zimbabwe is currently anchored on two principal Acts, namely the RDDC Act and the Town and Urban Councils Act and both Acts are silent on the implementation of PPPs as levers for development.

In most local Authorities in which key informants were drawn, there are few or no experts to comprehensively create and monitor the PPPs business and as such issues to do with experience gaps were cited.

In most local authorities in Zimbabwe, there are gaps regarding ease of doing business. On the same note, local councils are not investor-friendly. For instance, rather than local authorities knocking on the doors of prospective investors, the investors are knocking on the doors of councils without instant reply. Related to the above point is the issue of bureaucracy as there are too many steps, processes and resolutions before approval of investments. In most instances, it will take at least 3 years for an investor to partner and do business with local councils.

Respondents also cited the volatile political and macro-economic environment characterized by politically-motivated demonstrations, violence as well as deterioration in macro-economic fundamentals such as exchange rate volatility as well as an inflation of above 400 percent particularly between June 2019 and September 2020, as impediments to the sustainability of PPPs in Zimbabwe.

Respondents also cited lack of trust and confidence in the local government systems and processes as there are gaps in transparency and accountability. More importantly, there is goal-incompatibility between local councils and private investors. In most cases, local councils which are quasi-government institutions intend to break even and provide services at low cost while private players turn to maximize return on investment through charging exorbitant fees on partnership products and services.

\subsection{Discussion}

Apparently, PPPs uptake has increased globally because traditional sources of infrastructural financing through loans and Official Development Assistance (ODA) grants, local government and national budget allocations are not forthcoming due to strained financial resources. This scenario has resulted in infrastructural development gaps in road networks, water, electricity, among other public services.

Research has shown that global success stories such as Canada and India have embraced sustainable PPP frameworks focusing on competitive bidding in tenders, innovation to cut costs, incentives to ensure affordable fees and increase in ridership, community engagement, strong PPP unit, strong and independent regulators as well as aggressive promotion of PPP policy by regional and international development institutions such as the Asia Development Bank (AsDB), IMF, UNDP and World Bank.

Both key informant interviews in the agriculture and local governance sectors as well as documentary review point to political and economic uncertainty, gaps in legal and institutional frameworks, currency risk, inadequate financial resources as PPPs constraining factors. Specifically, the key informant interviews in the aforementioned sectors identify gaps in embracing the demographic dividends and community engagement; corruption; property rights gaps in the land tenure system, unfavourable ease and cost of doing business as impediments to sustainable PPP frameworks, hence, there is need for the government to apply maximum effort to close the identified gaps.

In its policy documents such as the October 2018 - December 2020 TSP and Vision 2030 blueprints, the new dispensation which is being led by President Mnangagwa has shown its renewed effort to attract-in private participation in the water, airport and road, energy, agriculture sectors, among others, with a view to revamp infrastructure in those sectors, with a long-term vision for Zimbabwe to attain an upper-middle income status of US\$ $3500-00$ by 2030 . Noteworthy is that while Zimbabwe has embraced PPPs towards revamping the energy, road, railway, agriculture sectors since 1994, PPPs in those sectors are under 'the emerging and developed phases', while in the local governance sector PPPs are still at the 'nascent stage' due to poorly defined legislative frameworks as well as lack of expertise to guide the implementation of PPP projects in this sector. Thus, the government should put maximum effort in every sector where PPPs are being embraced so that sustainable frameworks are developed to guarantee 'PPP mature market' for Zimbabwe. 


\section{CONCLUSION}

While noting that Zimbabwe is still on the 'nascent' and 'developing' stages in regard to the implementation of PPPs in the local governance and agriculture sectors respectively, the study concludes by recommending measures to enhance sustainable PPP frameworks in the above sectors and the PPP environment in general.

\subsection{Measures to strengthen sustainability of PPPs in the agriculture sector}

There is need for the government to refine and define the necessary frameworks such as one-stop-shop for PPPs to link to specific ministries and government departments. For example, linking of the Joint Venture Unit as a PPP unit within the Office of the President and Cabinet with some line ministries and government departments such as the Ministry of Agriculture, ARDA, among other government departments. This is meant to ensure effective coordination and supervision of PPP projects.

Government should ensure policy consistency with a view to improve predictability and certainty within the economic environment, a scenario which assist in investment planning and decisions. This entails inter alia, cabinet, civil society organizations as well as industry and commerce speaking with one voice regarding macro-economic issues and avoids big-bang approaches to policies and unnecessary policy reversals.

There is need to create a conducive environment to attract more investors. This can be achieved for example, through reducing corruption, improving the ease and cost of doing business through removing red tape in procurement as well as availing necessary incentives.

There is need to revamp public infrastructure. In this respect, the government should provide cash grants to revamp key enablers of doing business such as electricity infrastructure and road networks.

The government should make deliberate effort to harness the youth bulge for the sustainability of PPP projects as the youths constitute more than 62 percent of the population. Relatedly, in line with global demographic trends of shattering the glass ceiling, given that women constitute 52 percent of the population, there is need for the government to harness the demographic dividend through empowering women to participate in PPPs.

There is need to ensure community participation and buy-in into the PPP projects through roping-in traditional leaders into the design and monitoring of PPPs projects. Noteworthy is that if partnership players inculcates awareness to the community traditional leadership, the community will protect the PPP projects and ensure their sustainability. In addition to the above, to ensure sustainable PPP projects there is need for the PPP vehicles to comply with environment protection laws and regulations such as keeping the environment clean through avoiding air, water and land pollution.

\subsection{Measures to strengthen sustainability of PPPs in Local Authorities}

First, there is need to roll-out PPPs in-basket training workshops. In this respect, the CEOs, mayors, council chairpersons, heads of council departments, chairpersons of committees need to be abreast with PPP best practices. This move will improve capability of policy-makers in the implementation of PPPs.

Second, since local government is anchored on two principal Acts namely the RDDC Act and the Town and Urban Councils Act, both Acts are silent on the role of private participation in improving service delivery and there is need for deliberate efforts to insert a clause or chapter that calls for lesser time in PPP investment approvals. The Irish Local Authorities offer enviable performance in this regard as there is a circular on PPPs which impels local authorities to utilize PPPs in their endeavour to improve service delivery (Chara 2003).

Third, in order to improve sustainability of PPPs at local council level, there is need to ensure that at the Ministry of Local Government and Public Works level, an investment desk is established which will be liaising with Zimbabwe Investment and Development Agency (ZIDA). Relatedly, working in consultation with investment promotion authorities, the Ministry of Local Government should formulate policy documents on PPPs that can be endorsed and adopted by local authorities.

Fourth, there is need to establish a Code of Professional Conduct and Ethics in Local Authorities. This code will assist in enforcing good corporate governance ethos as it will increase transparency and accountability and minimize corruption vices. It will thus foster mutual trust and build confidence between partners.

Fifth, the local authority should set sweeteners or incentives for their partners through rewarding risk that is being met by the private players. In this respect, devolution funds that are being rolled-out to local authorities in the new dispensation should go a long way in covering-up for these incentives. However, the article argues that the issue government financial support should be 
used sparingly as specific PPP vehicles should not create a financial burden to the government or the local authority. In essence, financial and risk management responsibility should be given to the PPP vehicle created and leave the government or local authority with governance -related issues such as creating as well as strengthening institutional, regulatory and legal frameworks.

Six, there is need for the establishment of procurement management unit independent from both partners. Thus, there is need for the government to strike flexibility in procurement through embracing regional and local supplies in a liberalized manner, paying particular attention to Just-in-time culture. In addition to the above, there is need for government to strip other procurement regulations that delay or derail project implementation process.

\section{Acknowledgment}

Special thanks go to the officials from the Ministries of Lands, Agriculture, Water and Rural Resettlement as well as Local Government, Public Works and National Housing together with their private companies for allowing the provision of data that has enabled this research to see light of the day. May the Almighty God abundantly bless them in their policy endeavours.

\section{REFERENCES}

Online Journals, books and (institutional and academic) policy papers

Boudot, Y. (2014). Challenges and Issues of financing infrastructures - Case studies of public-private partnerships (PPP). Financing the Future, Infrastructure Development in Central Africa, Regional Conference, Yaounde, Cameroon, p. 1-16

Chara, A. (2003). Irish Local Authority PPPs: The Policy Framework for the development of Public-Private Partnerships within local government. Circular IPPP 4/2003. 19 December 2003: ppp-unit@enviro.ie. (Accessed 20 December 2020).

Chilean Concession law. (not dated). PPP Reference Guide (n. 4) 7*/PPP Knowledege lab, "PPP Reference Guide, Version 3: https://pppknowledgelab.org/guide/sections/83-what-is-the-ppp-reference-guide/ Accessed 20 October 2019.

Delmon, J. (2010). Understanding Options for Public-Private Partnerships in Infrastructure. Sorting out the forest from the trees: BOT, DBFO, DCMF, Concession, Lease. Policy Research Working Paper 5173, pp. 1-73, The World Bank (Finance Economics and Urban Development)

Dobbs, R et al. (January 2013) McKinsey Global Institute Report. Infrastructure Productivity: How to save \$1 trillion a year, New York McKinsey Global Institute, pp. 1-8: https://www.mcKinsey.com/industries/capital-projects-and-infrastructure/ourinsights/infrastructure-productivity. (Accessed 2 November 2019).

Economic Intelligence Unit (EIU). (2015). Evaluating the environment for public-private partnerships in Asia Pacific. The 2014 Infrascope, EIU limited and Asia Development Bank, pp. 1-81: https://www.eiu.com>topical-report.aspx?. (Accessed on 20 December 2019)

European Commission. (2003). Guidelines for Successful-Public-Private Partnerships, (2003) 16: https://ec.europa.eu/regionalpolicy/sources/docuge. (Accessed 4 September 2019).

Himmel, M and Siemiatycki, M. (2017). Infrastructure public-private partnerships as drivers of Innovation? Lessons from Ontario, Canada. Environment and Planning C: Politics and Space 2017. Vol. 35 (5). pp. 746 - 764

Massimo, C. (2014). Public-Private Partnerships Policy as a panacea to State Owned Enterprises: The Case of National Railways of Zimbabwe, Journal of Public Policy in Africa, Vol. 2: Issue 1, pp. 79-89

Nkomo, K and Nhema, A.G. (2015). Implementing Public-Private Partnerships (PPPs) in the transport sector in Zimbabwe: Challenges and prospects: Global Business and Economics Research Journal, Vol. 4 (7), pp. 40 - 70

Sulser, P.O. (2018). Infrastructure PPPs in the most challenging developing countries: Closing the gap, Euro-money Trading Ltd (International Financial Law Review), Great Britain, pp. 1-86. ISBN: 978-5272-2433-9

The Canadian Council for PPPs. (not dated.) Definitions and Models, Available on: http://www.pppcouncil.ca/web/knowledgecentre/what-are-P3s/definitions-models/. (Accessed 11 November 2019).

The Zimbabwe October 2018 - December 2020 Transitional Stabilization Programme Reforms Agenda (5 October 2018). Towards a Prosperous and Empowered Upper Middle Income Society by 2020, Harare 
United Nations Conference on Trade and Development. (2018). Investment Policy: What are PPPs?: https://investment-policyhub.unctad.org/pages/what-are-ppps. (Accessed 11 October 2019).

World Bank. (2019a). PPP Knowledge-Lab: What PPPs is not: Other types of Private Investment: https://pppknowledge.org/guide/sections/6-ppp-contract-types-and-terminology/. (Accessed 4 September 2019).

World Bank Group. (2019b). Public-Private Partnerships (PPPs): How can PPPs help deliver better services? World Bank Open Learning Campus in Partnership with Republic of Korea Ministry of Economy and Finance: https://www.worldbank.org/content/public-private-partnerships-ppp-how-can-ppps-help-better-services-o. (Accessed 4 September 2019).

World Bank Group. (not dated.) Concessions, Build-Operate-Transfer (BOT) and Design Build Operate (DBO) Projects, PublicPrivate Partnership in Infrastructure Resource Centre: https://www.ppp.worldbank.org/public-privatepartnership/agreements/concessions-bots-dbos/. (Accessed 20 November 2019).

Yadav, S and Yadav, N. (July - September 2008). Governance in India and Public-Private Partnership: A Paradigm Shift. Indian Journal of Public Administration. Vol. 3. pp. 638 - 653

Zinyama, I and Nhema, A.G. (2015). Public-Private Partnerships: A critical Review and lessons for Zimbabwe. Public Policy and Administration Research Vol. 5 (6), pp. 39-44

Zvoushe, H and Zhou, G. (2014). Public-Private Partnerships for Infrastructural Development in Africa: Prospects and Pitfalls, Journal of Public Policy in Africa, Vol. 2: Issue 1, pp. 18-33

\section{Newspapers, Magazines and Corporate Websites}

Bhoroma, V. (2018). Why PPPs are Evading Zimbabwe? (The Newsday of June 19): https://www.newsday.co.zw/why-ppps-areevading-zimbabwe/. (Accessed 20 October 2019).

Rusare, P. (2016). Success story of value-addition in Norton. (The Patriot of 26 May): www.thepatriot.co.zw/old-posts-/successstory-of-value-addition-in-norton/. (Accessed 20 September 2019).

Scoones, I. (2016). Can joint ventures revive large-scale commercial agriculture in Zimbabwe? (Zimbabwe Land: Debating Zimbabwe's land Reform): https://zimbabweland.word-press.com/2016/10/31/are-joint-ventures-with-parastatal-theroute-to-reviving-large-scale-commercial-agriculture-in-zimbabwe/. (Accessed 20 October 2019). 